NBER WORKING PAPER SERIES

\title{
THE REALLY LONG-RUN PERFORMANCE OF INITIAL PUBLIC OFFERINGS: THE PRE-NASDAQ EVIDENCE
}

\author{
Paul A. Gompers \\ Josh Lerner \\ Working Paper 8505 \\ http://www.nber.org/papers/w8505 \\ NATIONAL BUREAU OF ECONOMIC RESEARCH \\ 1050 Massachusetts Avenue \\ Cambridge, MA 02138 \\ October 2001
}

We thank Ken French for providing access to the historical size and book-to-market breakpoints, portfolio returns, and factor returns. Malcolm Baker, Gene Fama, Ken French, Andrew Metrick, Jay Ritter, Andrei Shleifer, Jeff Wurgler, and participants in the NBER Corporate Finance program meeting and the Harvard Business School Entrepreneurship Conference provided helpful comments. Malcolm Baker, Matt Bluestone, Eugene DeAngelis, Gene Divolio, Amit Doshi, Vedica Jain, Jason Jun, Nik Johnston, Darpan Kalra, Mbago Kaniki, Flora Kim, Tom Knox, Neil Lawande, Ethan Lebowitz, and Eitan Levisohn provided excellent research assistance. Special thanks go to Girts Graudins and Eric Nierenberg for their outstanding contributions to this project. Harvard Business School's Division of Research provided financial support. The views expressed herein are those of the authors and not necessarily those of the National Bureau of Economic Research.

(C) 2001 by Paul A. Gompers and Josh Lerner. All rights reserved. Short sections of text, not to exceed two paragraphs, may be quoted without explicit permission provided that full credit, including $\subset$ notice, is given to the source. 
The Really Long-Run Performance of Initial Public Offerings:

The Pre-NASDAQ Evidence

Paul A. Gompers and Josh Lerner

NBER Working Paper No. 8505

October 2001

JEL No. G24, G14

\begin{abstract}
$\underline{\text { ABSTRACT }}$
Financial economists in recent years have closely examined and intensely debated the performance of initial public offerings using data after the formation of NASDAQ. The paper seeks to shed light on this controversy by undertaking a large, out-of-sample study: we examine the performance for up to five years after listing of nearly 3,661 initial public offerings in the United States from 1935 to 1972. The sample displays some evidence of underperformance when event-time buy-and-hold abnormal returns are used. The underperformance disappears, however, when cumulative abnormal returns are utilized. A calendar-time analysis also shows that over the entire sample period-i.e., from 1935 to 1976 - IPOs return as much as the market. Finally, the intercepts in CAPM and Fama-French three-factor regressions are insignificantly different from zero, suggesting no abnormal performance.
\end{abstract}

Paul A. Gompers

Harvard Business School

Morgan 485

Boston, MA 02163

and NBER

Tel: 617-495-6297

Fax: 617-496-8443

Email: pgompers@hbs.edu
Josh Lerner

Harvard Business School

Morgan 395

Boston, MA 02163

and NBER

Tel: 617-495-6065

Fax: 617-496-7357

Email: jlerner@hbs.edu 


\section{Introduction}

Ritter (1991) and Loughran and Ritter (1995) document severe underperformance of initial public offerings (IPOs) during the past twenty years. In discussing these results, they suggest that investors may systematically be too optimistic about the prospects of firms that are issuing equity for the first time. Their results have inspired countless articles in the popular press about the danger of investing in IPOs, as well as academic research that has shown that underperformance extends to other countries as well as to seasoned equity offerings.

The results concerning IPO performance, however, are not uncontroversial. Brav and Gompers (1997) show that firms that go public do not perform worse than benchmarks matched on the basis of size and book-to-market ratios. In addition, they show that value weighting IPO returns dramatically reduces the measured underperformance. Finally, they argue that weighting returns in event time by the number of IPOs may overstate underperformance.

The debate about the underperformance of IPOs, however, may not easily be answered without out-of-sample tests. Most studies on the underperformance of IPOs have examined the same post-NASDAQ time period. Data from non-U.S. markets is not conclusive because of the shorter time periods employed and the cross sectional correlation between returns of IPOs in the U.S. and the return of IPOs in these other markets. Common economic shocks or common movements in fads and sentiment potentially drive these correlations.

In this paper we undertake a large, out-of-sample investigation of IPO underperformance. In particular, we gather information on the universe of firm-commitment IPOs in the United 
States from 1935 to 1972 and measure their returns for up to five years after listing. In order to compile this information, we hand-collected over one hundred and fifty thousand observations from such publications as the Bank and Quotation Record, the S\&P Dividend Guide, and the various Moody's manuals. This is the first large-scale examination of IPO returns prior to the creation of the NASDAQ exchange, and more than doubles the period over which the performance of U.S. IPOs can be observed. As such, it represents a potentially powerful sample to examine the performance of equity issuers.

The results demonstrate that the performance of IPOs from 1935 to 1972 depends upon the method of return measurement used. While the sample shows underperformance when performance is measured using value-weighted event-time buy-and-hold abnormal returns, this underperformance disappears when either equal-weighted buy-and-hold abnormal returns or cumulative abnormal returns are utilized. The calendar-time analysis shows that over the entire sample period-i.e., from 1935 to 1976-IPOs return as much as the market. Finally, in simple Capital Asset Pricing Model (CAPM) and Fama-French three-factor regressions, the intercepts are insignificantly different from zero or even significantly positive. The difference between the event-time and calendar-time results stems from the clustering of IPOs in periods immediately preceding poor IPO performance: IPOs and similar size and book-to-market stocks have lower returns after periods with heavy IPO issue volume, though the effects are not statistically significant.

The results raise questions concerning the interpretation of the underpeformance of IPOs seen in the NASDAQ era. The long-run performance of pre-NASDAQ IPOs depends 
considerably on the method for calculating returns and performance. While the results do not rule out the possibility of more broad-based sentiment-driven mispricing, they provide little support for a distinct IPO effect.

The rest of the paper is organized as follows. Section II reviews the relevant earlier literature. The data are described in Section III. The empirical analysis is discussed in Section IV. Section V concludes the paper.

\section{Literature review}

\section{II.A. Behavioral finance and IPOs}

Behavioral economists have demonstrated that individuals often violate Bayes' Rule and rational choice theories when making decisions under uncertainty in experimental settings (Kahneman and Tversky (1982)). In a similar vein, financial economists have also discovered long-run pricing anomalies that have been attributed to investor sentiment. Behavioral theories posit that investors give too much weight to recent results and trends. Eventually, overoptimistic investors are disappointed and subsequent returns decline.

To cite several important illustrations, DeBondt and Thaler $(1985,1987)$ demonstrate that buying past losers and selling past winners is a profitable trading strategy. Risk, as measured by beta or the standard deviation of stock returns, does not seem to explain the results. Lakonishok, Shleifer, and Vishny (1994) show that many "value" strategies also seem to exhibit abnormally high returns. These authors form portfolios based on earnings-to-price ratios, sales growth, earnings growth, or cash flow-to-price and find that "value" stocks outperform "glamour" stocks 
without appreciably affecting risk. Similarly, La Porta (1996) shows that a strategy of selling stocks with high forecasted earnings growth and buying companies with low projected earnings growth produces excess returns. These papers imply that investors are too optimistic about stocks that have had good performance in the recent past and too pessimistic about stocks that have performed poorly.

In addition to trading strategies based on accounting or stock market performance, researchers have examined financing events as sources of potential trading strategies. Theoretical work by Ross (1977) and Myers and Majluf (1984) suggests that the choice of financing strategy can send a signal to the market about firm valuation. Initial studies (e.g., Mikkelson and Partch (1986), Asquith and Mullins (1986)) focused on the market reaction around the time that equity or debt issues were announced. These works implicitly assumed that all information implied by the financing choice was fully and immediately incorporated into the company's stock price. The literature on long-run abnormal performance, on the other hand, examines the possibility that the market underreacts to the informational content of the financing event.

In particular, Ritter (1991) and Loughran and Ritter (1995) show that nominal five-year buy-and-hold returns are 50\% lower for recent IPOs (which earned 16\%) than they are for comparable size-matched firms (which earned 66\%). Teoh, Welch, and Wong (1998) show that IPO underperformance is positively related to the size of discretionary accruals in the fiscal year of the IPO. Larger accruals in the IPO year are associated with more negative performance. 
Teoh, et al. believe that the level of discretionary accruals is a proxy for earnings management and that the boosted earnings systematically fool investors.

On the other hand, papers by Brav and Gompers (1997) and Brav, Geczy, and Gompers (2000) show that equity-issuing firms, whether IPO or seasoned equity offering issuers, appear to perform like other long-standing public companies. In particular, Brav and Gompers show that even though the sample of IPOs underperforms broad market benchmarks, IPOs from 1975 to 1992 have five-year returns that are similar to size and book-to-market matched benchmarks. Similarly, value weighting IPO returns substantially reduces measured underperformance relative to all benchmarks.

\section{II.B. Performance measurement}

Another area of relevant research considers the choice of metric to measure firms' performance. Several recent papers inform our choice of tests of long-horizon abnormal performance. Barber and Lyon (1997), Kothari and Warner (1997), and Lyon, Barber, and Tsai (1999) provide thorough evidence about various methods of measuring abnormal performance. These papers do not find that one method is always preferred.

Fama (1998) and Mitchell and Stafford (2000) provide an additional assessment regarding the merits of such methodologies. They argue that abnormal performance measures such as cumulative abnormal returns (CARs) and time-series regressions are less likely to yield spurious rejections of market efficiency than methodologies that calculate buy-and-hold returns (BHARs) by compounding single period returns at a monthly frequency. First, the buy-and-hold method can 
magnify underperformance - even if it occurs in only a single period - as a consequence of compounding single-period returns. Second, distributional properties and test statistics for cumulative abnormal returns are better understood.

These problems can be illustrated by considering a firm that had a return of $-50 \%$ in the first year, and $+10 \%$ in the second and third years, while the market benchmark was flat during the first year and also returned $+10 \%$ during the second and third years. A buy-and-hold calculation will suggest that the company underperforms the index by over $60 \%$ (a return of $-39.5 \%$ for the company vs. that of $21 \%$ for the market), while the CARs will differ only by $50 \%$. As Brav, Geczy, and Gompers (2000) point out, the choice of CARs or BHARs largely depends upon the implicit trading strategy that is being assumed. We will report returns using both methodologies throughout the paper. ${ }^{1}$

\section{Data}

One of the main barriers to research in this area is the identification and characterization of IPOs prior to 1973. This section describes the procedures that we followed.

\section{III.A. Identifying the Sample}

While researchers examining IPOs undertaken in 1973 and thereafter can identify offerings through electronic databases and filings with the U.S. Securities and Exchange

\footnotetext{
${ }^{1}$ Among the concerns with the use of CARs is the methodology's tendency to misrepresent performance when returns are highly volatile. Consider a case where a firm had returns of $-50 \%$ in the first period and $+100 \%$ in the second period while the benchmark was flat in both periods. A buy-and-hold calculation would suggest that the excess return was zero, while the CARs would be computed to be $+50 \%$.
} 
Commission (SEC), research into earlier periods is more challenging. The Securities Data Company's Corporate New Issues database only extends back to 1970, and the detail of the information collected is scanty in earlier years. SEC filings prior to 1973 were not distributed by Disclosure and are stored in at least two poorly indexed and documented government archives.

Thus, we rely on a variety of secondary sources to identify the IPOs. We will review these in chronological order. For the period between July 1934 (the effective date of the Securities Act of 1933) and December 1949, we rely on the compilation, Issuer Summaries (Dean, Piel, and Steyer (1951)). This two-volume set was prepared by the defense counsel for the 17 investment banks in the antitrust case United States v. Henry Morgan, et al. ${ }^{2}$ As part of this litigation, in which the government alleged that the banks had conspired to monopolize underwriting activities, the banks compiled a listing of all U.S. security issues during this period. We only include underwritten IPOs of common stock that were executed with the services of an investment banker and were fully registered with the SEC, and where there was at least some primary component to the offering. ${ }^{3}$

For the period between 1950 and 1960, we employed the compilation Corporate Financing (Dealers' Digest Publishing Company (1961)), which was prepared by the publisher of the magazine Investment Dealers' Digest. The information from this volume was compiled from the semi-annual summaries of activity printed in that magazine. The editors explicitly

\footnotetext{
${ }^{2} 118$ F. Supp. 621 (S.D.N.Y. 1953).

${ }^{3}$ The purely secondary IPOs during this period were almost entirely of the type known as "special offerings," where trading was limited to the members of the exchange on which it was listed. These were not strictly comparable to the other offerings, and hence were deleted from the sample.
} 
modeled their compilation after the earlier Issuer Summaries. One exception was in its coverage. The volume eliminated offerings that were (i) not underwritten, (ii) unregistered, (iii) filed but not fully registered with the SEC (during this period, the issuers of offerings under $\$ 300,000$ could instead simply file a letter of notification with the SEC), or (iv) certain classes of secondary offerings that were not freely tradable after the offering. Since we had eliminated similar offerings from the offerings reported in Issuer Summaries, these deletions produce minimal biases. We again only included the IPOs of common stock in our sample.

Offerings in the period from 1960 through 1969 were identified from the volume, $A$ Decade of Corporate and International Finance: 1960-1969 (Hillstrom and King (1970)). This volume was also compiled from the records of Investment Dealers' Digest in conjunction with the Investment Bankers Association of America (the predecessor to the Securities Industry Association). The volume did not include non-registered offerings, those under $\$ 300,000$ (entitled to abbreviated registration under Regulation A), or non-underwritten offerings. We again only included the IPOs of common stock in our sample. ${ }^{4}$

The final period for which data was compiled was the years 1970 through 1972. In these years the records of Investment Dealers' Digest were computerized. These are now available through Securities Data Company (SDC), which acquired the magazine's database business in 1992. The criteria for the inclusion of offerings in the SDC compilation appear identical to those employed by Investment Dealers' Digest, reflecting the common origin of this data source. We

\footnotetext{
${ }^{4}$ This data set was at one point available in electronic form as well (Ibbotson (1975), Ibbotson and Jaffe (1975)), but this file has now apparently been lost.
} 
again only included the IPOs of common stock in our sample. Unfortunately, the records available through SDC are not complete. Thus, we hand-collected the missing information from the "New Market Names" section of the Investment Dealers' Digest, which summarized IPOs on a monthly or bi-monthly basis during this period.

Three methodological issues deserve notice. One complication was introduced by the fact that the volumes for the period 1934 through 1959 did not clearly distinguish between IPOs and seasoned equity offerings. In order to determine this, we checked the issues of Moody's and the Bank and Quotation Record to determine if the firm had been publicly traded before the offering. If so, we eliminated it as a possible IPO.

Firms that are recorded as having gone public, but never appeared in the compilation of stock data discussed below, introduced a second complication. In many cases, it appears that the compilations (particularly during the 1930s and 1940s) included offerings that were subsequently withdrawn for lack of investor interest. If the firm did not appear in the Bank and Quotation Record within twelve months of the reported IPO date, we deleted it from the sample.

Finally, assessing the completeness of the sample is exceedingly difficult. In particular, while the SEC produced at least three compilations of IPO activity during this period (U.S. Securities and Exchange Commission (1941), U.S. Congress (1963), U.S. Small Business Administration (1980)), their compilations are quite different in nature. In particular, most of the tabulations are of all unseasoned firms to file with the SEC, whether the offering was 
underwritten or not. The tabulations include many private placements and other offerings that were not fully registered with the SEC.

Table I summarizes the final sample of IPOs. There are a total of 3,661 offerings in the sample. The distribution over time is highly uneven. There is little IPO activity during the Great Depression and World War II. The number of offerings surged in the late 1950s and early 1960s and again in the late 1960s and early 1970s. The average IPO firm had a market value at the first available trading price of $\$ 89.1$ million in constant 1999 dollars (using the Consumer Price Index as a deflator), while the median firm had a market capitalization of $\$ 31.7$ million. Much like the recent samples of IPOs, the IPOs from 1935-1972 also had relatively low book-to-market ratios. The mean (median) book-to-market ratio in our sample is $0.443(0.305)$, indicating that the firms are primarily growth companies.

\section{III.B. Identifying the Stock Returns}

For each IPO, we sought to compute the five-year calendar and anniversary return. In order to do so, we needed to obtain eleven stock prices. These included the stock price immediately after the offering, on the five anniversaries of the offering, and at the end of the five Decembers after the offering.

The primary source of this information was the Bank and Quotation Record, a specialized publication of the Commercial and Financial Chronicle. ${ }^{5}$ This monthly periodical reports the

\footnotetext{
${ }^{5}$ This was the same source used by Jarrell (1981) and Simon (1989) who examined the returns of IPOs and seasoned offerings between 1926 and 1940. In each case, the sample consisted of less than 100 IPOs. This source was also used for at least three studies of returns during the 1960s.
} 
prices of a wide array of securities at the close of the previous month. The Bank and Quotation Record also indicates stock splits, name changes, and delistings, but its coverage does not appear to be comprehensive.

The use of the Bank and Quotation Record poses a variety of issues. First, not all securities appear in the listing immediately after their reported IPO date. We treat the first observation as the price immediately after the IPO, as long as it appears within twelve months of the reported IPO date. (If it does not appear within twelve months, we do not include the IPO in the sample, as discussed above.) In some cases, a stock price does not appear in a given anniversary month or December, but does so in the month immediately before and after the offering. In this case, we will use the average of the two prices. Occasionally, a company will disappear for an extended period (e.g., one year) and then reappear. In the case of absences of longer than three months, we check with the Wall Street Journal Index and Moody's guides to insure that this is not a new firm using the same name as an acquired or delisted firm.

Due to the poor coverage of stock splits and delistings by the Bank and Quotation Record, as well as its failure to record dividends, we supplemented its information with the Standard \& Poors' Dividend Record. We record from this volume all cash or stock dividends

Ibbotson (1975) examined returns from 120 IPOs between 1960 and 1969. Logue (1973) examined the returns of 250 IPOs issued between 1965 and 1969. McDonald and Fisher (1972) examined 142 IPOs issued in 1969. This may have also been the source of the data used by Stigler (1964), who examines the wealth relatives of several hundred IPOs (but does not compute traditional risk-adjusted returns). 
paid by the firm through its fifth anniversary. This compilation also has a much more comprehensive coverage of name changes, acquisitions, stock splits, and so forth.

Finally, for some of the firms that went public in our sample in 1968 and thereafter, we are able to obtain some returns data for the final observations from the tapes of the Center for Research in Securities Prices (CRSP).

\section{III.C. Supplemental Information}

A variety of additional data was collected about the firms from two data sources. The first of these were the various Moody's manuals, including the industrial, over-the-counter and utility editions. We determined from this source the book value of the common stock as well as the number of shares outstanding, using the edition published immediately after the IPO. Because of the difficulty of obtaining information on the market value of preferred stock in the early years, we computed the market and book value of the common stock only. In computing book equity, we included all forms of retained earnings, surplus, paid-in capital associated with common stock, and minority interests. We did not include reserves, contributions in aid, and other "liability-like" balance sheet entries. The market value was computed as the product of the number of shares of common stock outstanding after the IPO (or at the first period after the offering where this information could be ascertained from Moody's) and the first price observation of the common stock in the Bank and Quotation Record after the IPO.

We also checked firms that disappeared from the Bank and Quotation Record using the Wall Street Journal Index and Moody's guides. In particular, we sought to discern whether the 
firm was acquired (and if so, the acquisition price), liquidated, or delisted (and the final price in that case). While in many cases, we were unable to discern what happened to the firms from these sources, the unidentified disappeared firms were on average quite small. For these low priced firms that disappear, we assume a return of $-100 \%$ in the delisting year. We explore the impact of treating the disappeared firms in different ways, but find the changes have a minimal impact on the results.

We classified the IPOs into quintiles based on their market capitalization and book-tomarket ratio. We utilize the quintiles created by Davis, Fama, and French (2000). To get size breakpoints, firms are grouped on the basis of market capitalization at the beginning of a particular trading month. As in earlier research, the breakpoints are computed using only stocks trading on major exchanges: in this instance, the New York Stock Exchange (NYSE). Hence, Davis, Fama, and French allocate an equal number of NYSE stocks to one of five size quintiles. The size quintile breakpoints for each month are recorded. Similarly, each June the ratio of book equity to market equity is calculated for each firm on the NYSE. An equal number of firms is allocated to one of five book-to-market quintiles. The annual book-to-market breakpoints are then intersected with the size breakpoints to create twenty-five size and book-to-market portfolios.

Panel A of Table II summarizes the distribution of firms. Not surprisingly, more than one-half of the IPO sample falls into the $(1,1)$ portfolio, which is the collection of the smallest firms with the lowest book-to-market ratio. Overall, almost $90 \%$ of our IPOs are in the smallest size quintile of stocks when breakpoints are based on NYSE stocks. Less than $2 \%$ of our firms 
are in the largest two size quintiles. Similarly, $61 \%$ of our firms are in the lowest book-tomarket quintile. In addition, Panels B and C present the average size and book-to-market ratios for the IPOs in each of the twenty five size and book-to-market portfolios.

\section{Results}

\section{IV.A. Event-Time Returns}

In this section we present analyses of the returns of IPOs in event time; that is, measuring performance relative to the date of the IPO or the first stock price observation. Figure 1 provides an initial look at the results. We compute the abnormal return on the IPO in each year by subtracting the return (including any dividends) from one of two benchmarks: the CRSP valueweighted index and the return of the portfolio of firms with the same size and book-to-market ratio as the IPO. The data shows that abnormal returns are quite high in the first year relative to both benchmarks. Abnormal returns relative to the CRSP value-weighted index are negative in years two and three, but are positive in both years four and five. The abnormal returns relative to matched size and book-to-market portfolios follow a somewhat different pattern. Abnormal returns are high in the first year, negative in years two, three, and five, but positive in year four. The initial picture is one that does not generally suggest persistent and strong underperformance. Year-to-year performance appears to be quite random, as is suggested by Fama (1998).

In Table III, we compute the three- and five-year buy-and-hold return of the IPOs by compounding the annual return on the issuer firm (once again including any dividends). In Panels A and B, the returns are calculated for three and five years. If the IPO is acquired or delisted before the third or fifth anniversary, both the IPO returns and benchmark/market returns 
are set to zero in subsequent years. In Panels C and D, if the IPO firm is acquired or delisted before the third or fifth anniversary, we splice in the return of the IPO firm's matched size and book-to-market benchmark in subsequent years.

The results in Panels A and B show that the returns to IPOs severely underperform the market on a buy-and-hold return basis. IPOs return $8.5 \%$ over three years and only $11.4 \%$ over five years. The underperformance relative to the CRSP value-weighted index is $-16.7 \%$ after three years and $-21 \%$ after five years. These patterns largely match the results found in the data after 1972 .

In the last two columns of Table III, we compute the value-weighted returns over threeand five-year periods. (We use the market capitalization of the firm as weights, computed using the first market price found in the Bank and Quotation Record.) Unlike the post-1972 period, performance is even worse for the larger IPOs. Returns drop to $6.3 \%$ after three years and $11 \%$ after five years. Underperformance relative to the CRSP value-weighted index is $-20 \%$ after three years and $-35 \%$ after five years. (See below for a discussion of the statistical significance of the results.)

Brav and Gompers (1997) show that the underperformance of IPOs after 1972 is eliminated when firms are matched to portfolios based on size and book-to-market. In our sample of IPOs, we find mixed evidence of a similar reduction in underperformance. Underperformance after three years is smaller $(-8.4 \%)$, but underperformance after five years is larger, $-33 \%$, when IPO returns are adjusted for size and book-to-market benchmark returns. 
This indicates that the returns of IPO firms initially mimic the poor performance of small, low book-to-market firms, but perform worse over longer time horizons (see Figure 1). The matched size and book-to-market portfolios in our sample are relatively free from IPO firms because Davis, Fama, and French only allocate NYSE firms to the benchmark portfolios. It was very rare for firms that had recently gone public to list on the NYSE during these years.

While the buy-and-hold abnormal returns in Table III are quite negative, suggesting severe IPO underperformance, conducting standard t-test measurements for statistical significance can produce misleading inferences. Consistent with the findings of Barber and Lyon (1997) and Kothari and Warner (1997), the buy-and-hold equal-weighted series exhibits large positive skewness, yielding misspecified t-statistics. In contrast, the five-year valueweighted buy-and-hold abnormal returns demonstrate negative skewness.

Following Lyon, Barber, and Tsai (1999), we employ a bootstrapped skewness-adjusted $\mathrm{t}$-statistic to correct the negatively biased t-statistics. We draw 5,000 resamples of size $\mathrm{n}$ (in this case, $n=100$ ), with replacement, from each return series and calculate a skewness-adjusted tstatistic for each sample, given by:

$$
\begin{aligned}
& S=\frac{\overline{A R_{t}}}{\sigma\left(A R_{t}\right)} \\
& \hat{\gamma}=\frac{\sum_{i=1}^{n}\left(A R_{i t}-\overline{A R_{t}}\right)^{3}}{n \sigma\left(A R_{t}\right)^{3}}
\end{aligned}
$$

where: 


$$
t=\sqrt{n}\left(S+\frac{1}{3} \hat{\gamma} S^{2}+\frac{1}{6 n} \hat{\gamma}\right)
$$

Critical values for skewness-adjusted t-statistics are then calculated based on the resamples; these values represent the cutoffs at which a null hypothesis that average buy-andhold returns are zero can be rejected for a give significance level. These critical values are obtained by solving:

$$
\operatorname{Pr}\left[t_{s a}^{b} \leq x_{1}^{*}\right]=\operatorname{Pr}\left[t_{s a}^{b} \leq x_{u}^{*}\right]=\frac{\alpha}{2}
$$

The skewness-adjusted t-statistic calculated for each of the actual buy-and-hold return series is then compared to these bootstrapped critical values to determine whether any underperformance (or overperformance) is found to exist.

While Lyon, Barber, and Tsai (1999) and Sutton (1993) find these bootstrapped critical values preferable to the standard normal distribution criterion, the effect in our study is minimal. For the equal-weighted buy-and-hold returns, applying the correction above produces transformed t-statistics that are insignificant using either the bootstrapped or normal critical values. Conversely, the five-year value-weighted returns are always significant at the one percent level, irrespective of the cut-off used. The only difference arises for the three-year value-weighted buy-and-hold abnormal IPO returns relative to the CRSP value-weighted index: using the bootstrapped critical values reduces significance from the one percent to the five percent level. 
The results in Panel C and D are consistent with the earlier results. Splicing in the size and book-to-market benchmark returns leave underperformance relative to the CRSP valueweighted index quite significant. Again, performance of the IPO portfolio is quite similar to that of the size and book-to-market matched firms for the three-year horizon, but not for the five-year time period. The effect of splicing in missing observations with the benchmark return is to increase somewhat the three-year returns, while increasing the five-year returns by a large amount.

In Table IV, we calculate abnormal performance using the cumulative abnormal return methodology. As Fama (1998) and Mitchell and Stafford (2000) argue, CARs may be a better, less biased method to calculate long-horizon returns because it eliminates the compounding effect of a single year's poor performance. Abnormal returns are calculated by subtracting benchmark returns from the IPO firm's return. We calculate CARs by summing annual abnormal returns over three or five years. In Panels A and B, returns are calculated for three and five years, with the IPO returns and benchmark/market returns set to zero if the firm is acquired or delisted. In Panels C and D, we again splice in the return of the firm's matched size and book-to-market benchmark if the firm delists prior to its third or fifth anniversary.

Once performance is measured using CARs, we get a different picture of long-run performance. Half of the equal-weighted CARs in Panels A and B are actually positive. Value weighting tends to increase the returns somewhat. Nevertheless, none of the CARs are statistically different from zero. In Panels C and D, in which we splice size and book-to-market benchmark returns for the IPO firm returns upon a delisting, the CARs are again insignificantly 
different from zero. It appears, therefore, that this correction has only a modest effect, whether on the buy-and-hold abnormal returns and cumulative abnormal returns of the IPO firms.

Table V highlights the extent to which the event-time returns vary across time. The fiveyear returns are calculated for all firms going public in a given year. These tables splice in the benchmark returns for firms that are acquired or delisted before the end of the period, as is done in Panels C and D of Tables III and IV. The results show that the cohorts with the greatest number of offerings, from 1968 to 1972, have strongly negative returns. This accounts for the underperformance of IPOs when measured in event time. Half of our IPOs occur between 1968 and 1972. Because of the multiplicative effect discussed in Section II, the results tend to be more volatile when buy-and-hold returns are calculated: the "good" cohorts have more positive returns than those computed using CARs, and the poor ones have more negative ones.

\section{IV.B. Calendar-Time Returns}

In order to address potential problems with event-time returns, we examine calendar-time returns for our sample of IPO firms. In order to examine the calendar-time performance, we calculate returns for all firms that were already public at the beginning of the year and do not celebrate the fifth anniversary of their IPO by the end of the year. Returns are again equal- and value-weighted.

In Figure 2, we compare the calendar-time performance of the IPO portfolio relative to both the CRSP value-weighted index and the matched size and book-to-market benchmarks. These reference portfolios are presented on both an equal- and value-weighted basis. We see 
from the results that the IPO firms appear to have time-series returns that are not strikingly different from the market. The equal-weighted IPOs perform substantially better than the CRSP value-weighted index and matched size and book-to-market benchmarks. The value-weighted IPOs, however, underperform all three benchmarks. Unlike in the NASDAQ era, during these years large IPOs actually performed worse than small offerings.

Table VI computes the returns of the IPO portfolios in each calendar year. For each year, we compute the equal- and value-weighted returns for all IPOs in the sample that have gone public in the past five years, and compare it to various market benchmarks. The average return using three of the four approaches is positive. (Again, value weighting the IPOs reduces the level of returns.) It is important to note the implications of treating each calendar year equally: during the early and mid 1970s, when the most IPOs are in the sample, the returns were quite negative (at least relative to the CRSP value-weighted index).

We also report the return of the $(1,1)$ portfolio $^{6}$ net of the CRSP value-weighted index. This is highly correlated with the IPO returns. For instance, the correlation coefficient of the excess return of the $(1,1)$ portfolio over the CRSP value-weighted index and the excess return of the value-weighted IPO return series (net of the CRSP value-weighted index) is 0.689 (with a pvalue of .000).

\footnotetext{
${ }^{6}$ As noted above, the $(1,1)$ portfolio contains those firms that are in the smallest size quintile and the smallest book-to-market quintile based on NYSE breakpoints.
} 
The negative correlation between IPO volume and IPO returns is highlighted in Table VII. The correlation between the size of the portfolio (the volume of IPOs in the past five years, less any delistings) and the annual returns net of the CRSP value-weighted index is about -0.1 , though not statistically significant. Loughran and Ritter (2000) argue that managers at IPO firms time market-wide mispricing, e.g., managers choose to issue when similar firms are severely overvalued. As such, periods following heavy IPO volumes are likely to be followed by particularly poor IPO performance and by particularly poor returns of the $(1,1)$ portfolio. While the pattern of the results is consistent with their suggestions, the correlation is not statistically significant and appears to be driven by a few outliers.

\section{IV.C. CAPM and Fama-French Three-Factor Regressions}

If IPOs underperform on a risk-adjusted basis, portfolios of IPOs should consistently underperform relative to an explicit asset pricing model. Recent work by Fama and French $(1992,1993,1995,1996)$ indicates that a three-factor model may explain the cross section of stock returns. Their three factors are RMRF, which is the excess return on the value-weighted market portfolio; SMB, the return on a zero investment portfolio formed by subtracting the return on a large firm portfolio from the return on a small firm portfolio; and HML, the return on a zero investment portfolio calculated as the return on a portfolio of high book-to-market stocks minus the return on a portfolio of low book-to-market stocks.

As in Fama and French's work, we use the intercept from time-series regressions as an indicator of risk-adjusted performance of the pre-NASDAQ IPOs. The intercepts in these regressions have an interpretation analogous to Jensen's alpha in the CAPM framework. This 
approach has the added benefit that we can make statistical inferences given the assumption of multivariate normality of the residuals.

This approach has a disadvantage, though: it weights each month equally in minimizing the sum of squares. If underperformance is correlated with the number of IPOs in our portfolios, the Fama-French results will reduce the measured underperformance. We will address this deficiency by also estimating returns weighted by the square root of the number of IPOs in the portfolio.

Table VIII presents the three-factor time-series regression results. Annual returns of the IPO portfolio returns are regressed on either RMRF for CAPM analysis or on RMRF, SMB, and HML for the Fama-French three-factor analysis. The intercepts in the simple CAPM are insignificantly different from zero. In the equal-weighted Fama-French three-factor regression, it is actually positive and significant at the one-percent confidence level. When the IPOs are value weighted, the performance is again poorer: the intercept is still positive but insignificant. Overall, these results confirm the time-series analysis above. IPOs do not appear to underperform on a calendar-time basis.

Panel B presents the Fama-French regressions weighted by the square root of the number of firms in the IPO portfolio in each year. Once again, the intercepts in the CAPM regressions are not different from zero, while in the three-factor regressions it is positive and significant in the equal-weighted case. The primary effect of weighting is to raise the coefficients on the 
RMRF factor, which suggests that the IPO firms reflected the overall market's movements in a particularly sharp way in the late 1960 s and early 1970 s.

This final analysis suggests some more general thoughts about the performance of the pre-NASDAQ population of IPOs. The performance patterns appear to closely reflect those of small growth firms more generally. There seems to be little evidence of a distinct IPO effect in these years.

\section{Conclusion}

This paper has sought to assess the performance of IPOs by examining the period before the creation of NASDAQ. By considering a period where returns of IPOs have not been systematically examined, we hope to shed light on whether the poor performance is driven by some fundamental behavioral anomaly or rather is just an idiosyncratic feature of the recent time period that has been the focus of prior academic studies. Pre-NASDAQ IPOs represent a potentially powerful out-of-sample test of IPO underperformance. Papers that examine IPO performance in other countries, as works such as Rouwenhorst (1998) highlight, may be finding similar patterns because of common economic factors or common investor biases across countries at the same time.

In a sample of over 3,661 IPOs between 1935 and 1972, we find underperformance when event-time buy-and-hold abnormal returns are used, but even this result is not consistently statistically significant. The underperformance disappears when we use cumulative abnormal returns. A calendar-time analysis shows that IPOs return at least as much as the market over the 
entire sample period. Finally, the intercepts in CAPM and Fama-French three-factor regressions are insignificantly different from or even greater than zero. In short, the relative performance of IPO sample depends on the method of examining performance. One methodology suggests that this sample underperforms; others suggest superior performance.

Our analysis of pre-NASDAQ IPOs serves to underscore the questions about IPO performance raised in Brav and Gompers (1997). The weakness of the evidence for underperformance and the failure to observe a consistent pattern raise doubts about whether a unique IPO effect indeed exists. Is there a real behavioral anomaly at work here, or rather is the poor performance of the offerings in the NASDAQ era simply a historical accident? Fama (1998) suggests that spurious anomalies can be anticipated when stock returns are examined repeatedly.

To be sure, it is possible that sentiment or fads are moving stock returns. These fads or sentiments would have to affect a broader set of firms than just IPO firms. Future tests of market efficiency need to look beyond individual anomalies and address broader market movements if they are to shed more light on this debate. 


\section{References}

Asquith, Paul, and David Mullins, 1986, Equity issues and offering dilution, Journal of Financial Economics 15, 61-89.

Barber, Brad, and John Lyon, 1997, Detecting long-run abnormal stock returns: The empirical power and specification of test statistics, Journal of Financial Economics 43, 341-372.

Brav, Alon, Chris Geczy, and Paul A. Gompers, 2000, Is the abnormal return following equity issuances anomalous?, Journal of Financial Economics 56, 209-249.

Brav, Alon, and Paul A. Gompers, 1997, Myth or reality? The Long-run underperformance of initial public offerings: Evidence from venture and nonventure capital-backed companies, Journal of Finance 52, 1791-1821.

Davis, James L., Eugene Fama, and Kenneth French, 2000, Characteristics, covariances, and average returns: 1929 to 1997, Journal of Finance 55, 389-406.

De Bondt, Werner, and Richard Thaler, 1985, Does the stock market overreact?, Journal of Finance 40, 793-808.

De Bondt, Werner, and Richard Thaler, 1987, Further evidence on investor overreaction and stock market seasonality, Journal of Finance 42, 557-581.

Dealers' Digest Publishing Company, 1961, Corporate Financing, 1950-1960, New York, Dealers' Digest Publishing Company.

Dean, Arthur H., William Piel, Jr., and Roy H. Steyer, 1951, Issuer Summaries: Securities Issues in the United States-July 26, 1933 to December 31, 1949, New York, privately printed.

Fama, Eugene F., 1998, Market efficiency, long-term returns, and behavioral finance, Journal of Financial Economics 49, 283-306.

Fama, Eugene, and Kenneth French, 1992, The cross-section of expected stock returns, Journal of Finance 47, 427-465.

Fama, Eugene, and Kenneth French, 1993, Common risk factors in the returns of stocks and bonds, Journal of Financial Economics 33, 3-55.

Fama, Eugene, and Kenneth French, 1995, Size and book-to-market factors in earnings and returns, Journal of Finance 50, 131-156.

Fama, Eugene, and Kenneth French, 1996, Multifactor explanations of asset pricing anomalies, Journal of Finance 51, 55-84. 
Hillstrom, Roger, and Robert King, 1970, A Decade of Corporate and International Finance, 1960-1970, New York, Investment Dealers Digest.

Ibbotson, Roger G., 1975, Price performance of common stock new issues, Journal of Financial Economics 2, 232-272.

Ibbotson, Roger G., and Jeffrey F. Jaffe, 1975, "Hot issue" markets, Journal of Finance 30, 1027-1042.

Jarrell, Gregg A., 1981, The economic effects of federal regulation of the market for new security issues, Journal of Law and Economics 24, 613-686.

Kahneman, Daniel, and Amos Tversky, 1982, Intuitive prediction: Biases and corrective procedures, In Daniel Kahneman, Paul Slovic, and Amos Tversky (eds.), Judgement under Uncertainty: Heuristics and Biases, London, Cambridge University Press.

Kothari, S.P., and Jerry Warner, 1997, Measuring long-horizon security price performance, Journal of Financial Economics 43, 301-339.

La Porta, Rafael, 1996, Expectations and the cross-section of stock returns, Journal of Finance 51, 1715-1742.

Lakonishok, Josef, Andrei Shleifer, and Robert Vishny, 1994, Contrarian investment, extrapolation, and risk, Journal of Finance 49, 1541-1578.

Logue, Dennis E., 1973, On the pricing of unseasoned equity offerings, Journal of Financial and Quantitative Analysis 8, 91- 103.

Loughran, Tim, and Jay Ritter, 1995, The new issues puzzle, Journal of Finance 50, 23-52.

Loughran, Tim, and Jay Ritter, 2000, Uniformly least powerful tests of market efficiency, Journal of Financial Economics 55, 361-390.

Lyon, John D., Brad M. Barber, and Chih-Ling Tsai, 1999, Improved methods for tests of abnormal long-run stock returns, Journal of Finance 54, 165-201.

McDonald, Jack G., and A.K. Fisher, 1972, New issue stock pricing behavior, Journal of Finance 27, 97-102.

Mikkelson, Wayne, and M. Megan Partch, 1986, Stock price effects and costs of secondary distributions, Journal of Financial Economics 15, 31-60.

Mitchell, Mark L., and Erik Stafford, 2000, Managerial decision making and long-term stock price performance, Journal of Business 73, 287-329. 
Myers, Stewart, and N.S. Majluf, 1984, Corporate financing and investment decisions when firms have information that investors do not have, Journal of Financial Economics 13, 187-221

Ritter, Jay, 1991, The long-run performance of initial public offerings, Journal of Finance 42, 365-394.

Ross, Stephen, 1977, The determination of financial structure: The incentive signaling approach, Bell Journal of Economics 8, 23-40.

Rouwenhorst, K. Geert, 1998, International momentum strategies, Journal of Finance 53, 267284.

Simon, Carol J., 1989, The Effect of the 1933 Securities Act on investor information and the performance of new issues, American Economic Review 79, 295-318.

Stigler, George J., 1964, Public regulation of securities markets, Journal of Business 37, 117142.

Sutton, Clifton, 1993, Computer-intensive methods for tests about the mean of an asymmetrical distribution, Journal of the American Statistical Association 88, 802-808.

Teoh, Siew, Ivo Welch, and T.J. Wong, 1998, Earnings management and the long-run performance of initial public offerings, Journal of Finance 53, 1935-1974.

U.S. Congress, House of Representatives, Committee on Interstate and Foreign Commerce, 1963, Report of Special Study of the Securities Markets of the Securities and Exchange Commission, Part 1 (House Document 95, Part $1,88^{\text {th }}$ Congress, $1^{\text {st }}$ Session), Washington, U.S. Government Printing Office.

U.S. Securities and Exchange Commission, Trading and Exchange Division, Research and Statistics Section, 1941, Sales Record of Unseasoned Registered Securities, 1933-1939, Washington, U.S. Securities and Exchange Commission.

U.S. Small Business Administration, Office of the Chief Counsel for Advocacy, and U.S. Securities and Exchange Commission, Directorate of Economic and Policy Research, 1980, Initial Public Offerings of Common Stock: The Role of Regional Broker-Dealers in the Capital Formation Process: Phase I Report, Washington, U.S. Government Printing Office. 


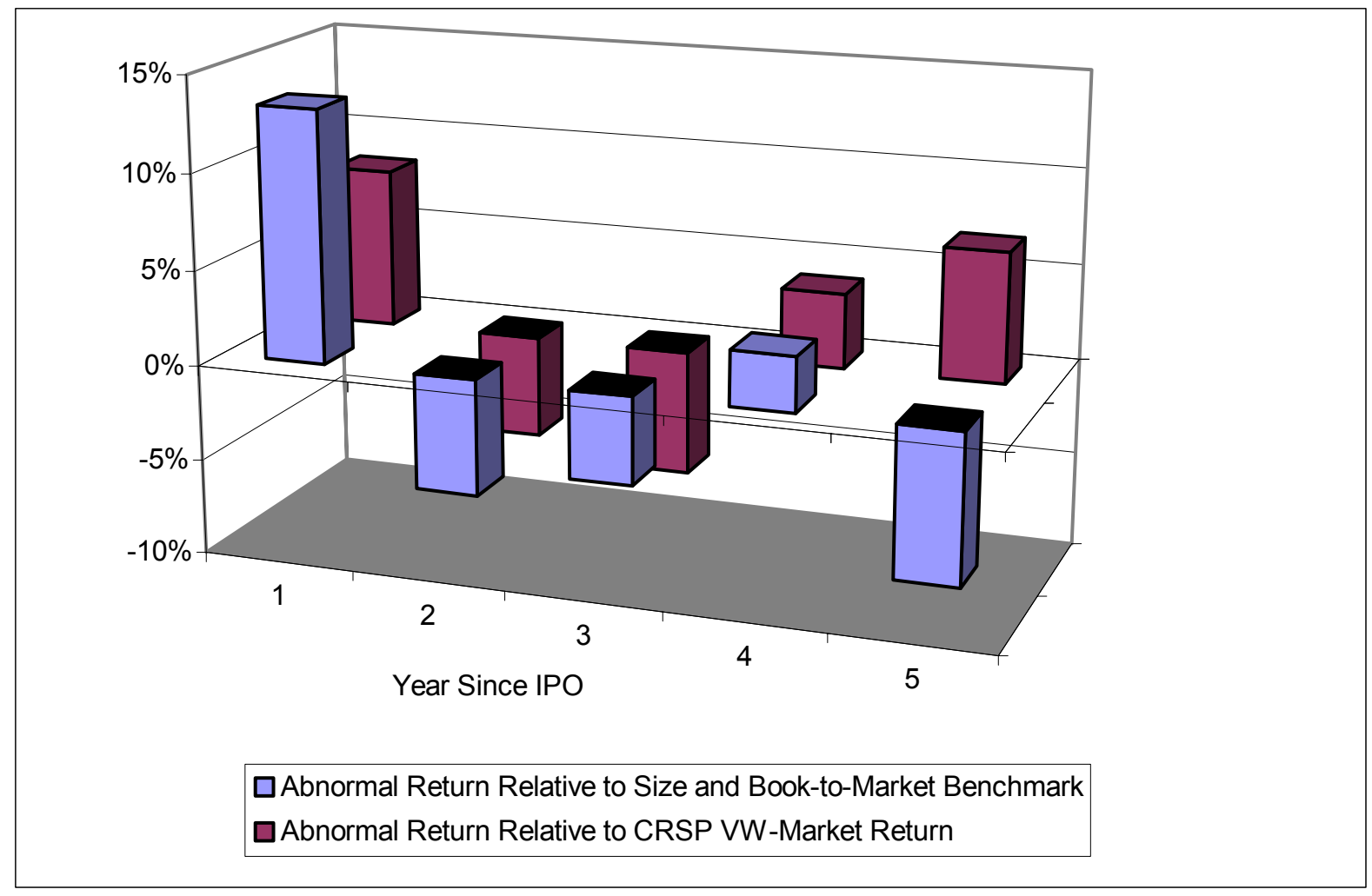

Figure 1. Average annual abnormal return. The sample is 3,661 identified IPOs from 1935 to 1972 . The equal-weighted average event-time annual abnormal return is plotted for years one through five after the IPO. Abnormal returns are calculated by taking the equal-weighted average annual return on the IPOs minus the equal-weighted return on the annual return on the CRSP value-weighted index or the appropriate size and book-to-market matched portfolio over the same time period. 


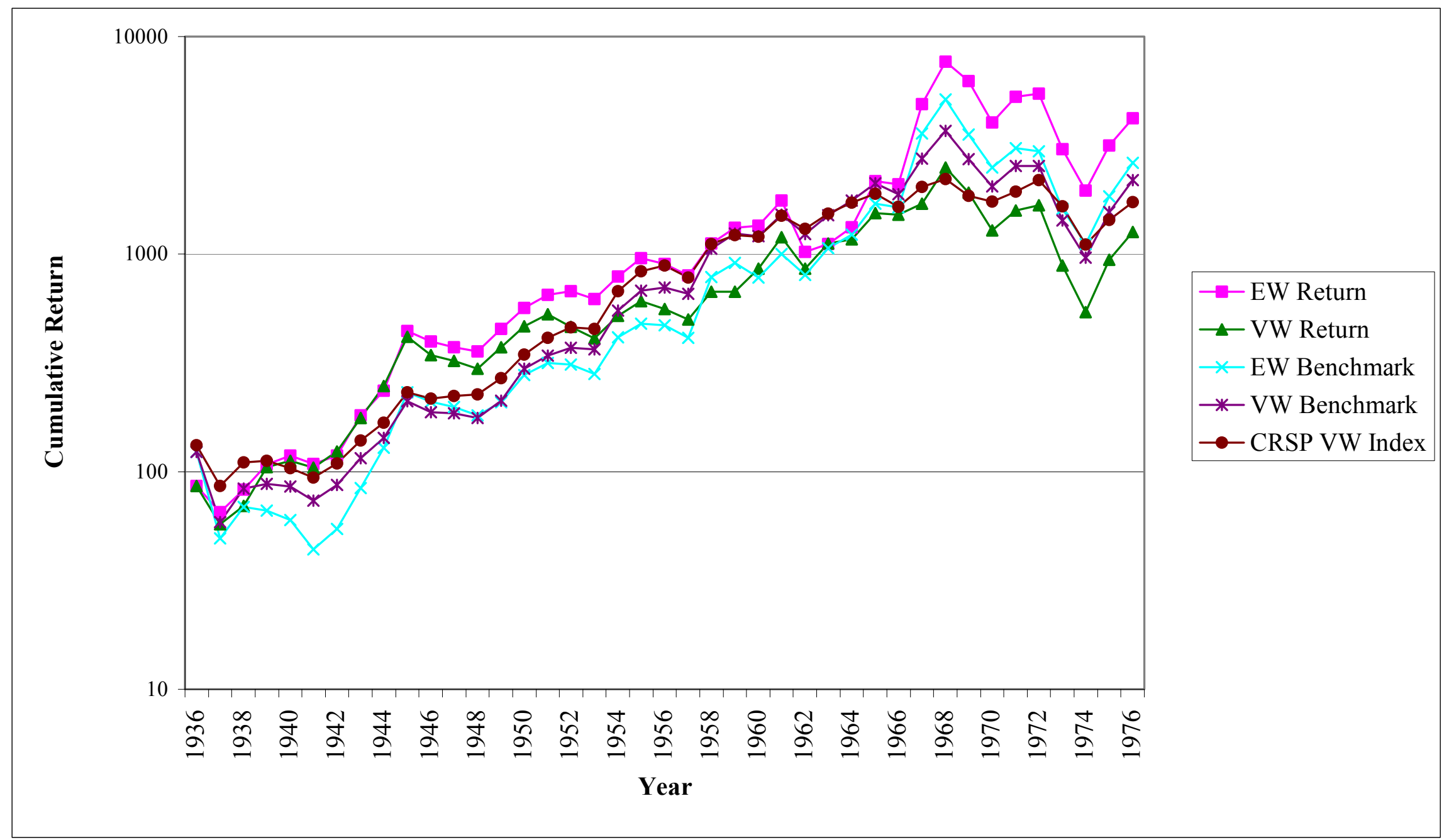

Figure 2. Calendar-time returns for initial public offerings. The sample is 3,661 identified IPOs from 1935 to 1972 . The compounded annual return on all IPOs in the sample that had gone public within the previous five years is compared to the compounded annual return on the CRSP value-weighted index and the average matched size and book-to-market benchmark return. 


\section{Table I}

\section{Sample of Initial Public Offerings}

The sample is 3,661 identified IPOs from 1935 through 1972. Panel A presents the year of the IPOs in our samples. Panel B presents the average, median, $25^{\text {th }}$ percentile, and $75^{\text {th }}$ percentile rankings of market capitalization at the close of the month of the IPO (in constant 1999 dollars adjusting for the Consumer Price Index) and the ratio of book equity value to market equity value.

Panel A: Dates of IPOs

\begin{tabular}{|c|c|c|c|c|c|c|c|c|c|c|c|c|c|c|c|c|c|c|c|}
\hline Year & 1935 & 1936 & 1937 & 1938 & 1939 & 1940 & 1941 & 1942 & 1943 & 1944 & 1945 & 1946 & 1947 & 1948 & 1949 & 1950 & 1951 & 1952 & 1953 \\
\hline Number of IPOs & 1 & 12 & 2 & 3 & 4 & 8 & 8 & 3 & 1 & 7 & 19 & 51 & 24 & 15 & 5 & 33 & 31 & 29 & 23 \\
\hline$\overline{\text { Year }}$ & 1954 & 1955 & 1956 & 1957 & 1958 & 1959 & 1960 & 1961 & 1962 & 1963 & 1964 & 1965 & 1966 & 1967 & 1968 & 1969 & 1970 & 1971 & 1972 \\
\hline Number of IPOs & 27 & 49 & 45 & 41 & 47 & 122 & 216 & 321 & 236 & 31 & 66 & 66 & 62 & 92 & 378 & 683 & 228 & 204 & 448 \\
\hline Total & 3,661 & & & & & & & & & & & & & & & & & & \\
\hline
\end{tabular}

Panel B: Summary Statistics

\begin{tabular}{lcccc}
\hline & Mean & 25th Percentile & Median & 75th Percentile \\
\hline Market Value & $\$ 89,089,000$ & $\$ 15,454,000$ & $\$ 31,706,000$ & $\$ 66,756,000$ \\
Book-to-Market & 0.443 & 0.143 & 0.305 & 0.552 \\
\hline \hline
\end{tabular}


Table II

\section{Size and Book-to-Market Portfolio Breakdown for IPO Sample}

The sample is 3,661 identified IPOs from 1935 through 1972. Size breakpoints are formed monthly by dividing all NYSE stocks into five size groups with equal number of firms in each group. Book-to-market breakpoints are formed annually with equal numbers of NYSE firms allocated to each of five book-to-market portfolios. The intersection of these quintile breakpoints results in 25 possible allocations. Panel A presents the fraction of our IPO sample that is allocated to each size and book-to-market portfolio. Panel B gives the average market value of the IPOs (in constant 1999 dollars) in each portfolio. Panel C presents the average book-to-market ratio for our IPOs by portfolio.

Panel A: Distribution of IPOs

\begin{tabular}{|c|c|c|c|c|c|c|}
\hline \multirow[b]{2}{*}{ Size Quintile } & \multicolumn{6}{|c|}{ Book-to-Market Quintile } \\
\hline & Lowest & 2 & 3 & 4 & Highest & Total \\
\hline Smallest & $53.0 \%$ & $16.1 \%$ & $8.8 \%$ & $4.6 \%$ & $6.6 \%$ & $89.1 \%$ \\
\hline 2 & $4.5 \%$ & $1.1 \%$ & $0.6 \%$ & $0.4 \%$ & $0.1 \%$ & $6.6 \%$ \\
\hline 3 & $1.8 \%$ & $0.4 \%$ & $0.4 \%$ & $0.1 \%$ & $0.0 \%$ & $2.8 \%$ \\
\hline 4 & $0.7 \%$ & $0.1 \%$ & $0.1 \%$ & $0.0 \%$ & $0.0 \%$ & $1.0 \%$ \\
\hline Biggest & $0.5 \%$ & $0.0 \%$ & $0.0 \%$ & $0.0 \%$ & $0.0 \%$ & $0.6 \%$ \\
\hline Total & $60.5 \%$ & $17.7 \%$ & $10.0 \%$ & $5.1 \%$ & $6.8 \%$ & $100.0 \%$ \\
\hline
\end{tabular}

Panel B: Size by Portfolio.

\begin{tabular}{rrrrrr}
\hline & \multicolumn{5}{c}{ Book-to-Market Quintile } \\
Size Quintile & \multicolumn{1}{c}{ Lowest } & \multicolumn{1}{c}{ 2 } & \multicolumn{1}{c}{ H } & \multicolumn{1}{c}{ Highest } \\
\hline Smallest & $\$ 45,600,000$ & $\$ 33,700,000$ & $\$ 35,400,000$ & $\$ 28,600,000$ & $\$ 17,400,000$ \\
2 & $\$ 198,900,000$ & $\$ 137,600,000$ & $\$ 134,700,000$ & $\$ 140,400,000$ & $\$ 200,600,000$ \\
3 & $\$ 378,500,000$ & $\$ 250,300,000$ & $\$ 242,300,000$ & $\$ 175,300,000$ & - \\
4 & $\$ 812,400,000$ & $\$ 307,700,000$ & $\$ 288,000,000$ & - & - \\
Biggest & $\$ 5,398,200,000$ & $\$ 795,200,000$ & & - & $\$ 490,800,000$ \\
\hline
\end{tabular}


Table II (continued)

Panel C: Book-to-Market Ratio by Portfolio.

\begin{tabular}{|c|c|c|c|c|c|}
\hline \multirow[b]{2}{*}{ Size Quintile } & \multicolumn{5}{|c|}{ Book-to-Market Quintile } \\
\hline & Lowest & 2 & 3 & 4 & Highest \\
\hline Smallest & 0.180 & 0.474 & 0.687 & 0.978 & 2.174 \\
\hline 2 & 0.205 & 0.648 & 0.807 & 1.114 & 1.125 \\
\hline 3 & 0.213 & 0.513 & 0.799 & 0.792 & - \\
\hline 4 & 0.151 & 0.793 & 0.846 & - & . \\
\hline Biggest & 0.136 & 0.783 & - & - & 0.732 \\
\hline
\end{tabular}


Table III

Three- and five-year post-initial public offering (IPO) buy-and-hold returns versus various benchmarks.

The sample is 3,661 identified IPOs from 1935 through 1972. Three- and five-year buy-and-hold abnormal returns (both equal-weighted and value-weighted) are compared with alternative benchmarks. In the first row of each panel, we employ the CRSP value-weighted index as the benchmark. Value-weighted results are adjusted for inflation. Row two of each panel presents abnormal performance measured relative to attributebased portfolios. Size and book-to-market portfolios are generated by first forming size quintile breakpoints using NYSE firms only. These quintiles are split further into book-to-market quintiles using NYSE breakpoints only. The universe of NYSE stocks is allocated into the resulting 25 portfolios and equalweighted monthly returns are calculated. The breakpoints for these portfolios are recalculated annually. Buyand-hold returns are generated by compounding annual returns starting in the first month that a stock price is found in the Bank and Quotation Record following the equity issue. Abnormal return is the simple difference between IPO three- or five-year average return and the corresponding benchmark. In Panels A and B, if the IPO delists before the fifth anniversary we compound the return up until the delisting year. In Panels $\mathrm{C}$ and $\mathrm{D}$, if the IPO delists before the fifth anniversary, we splice in the return of the matched size and book-tomarket benchmark.

\begin{tabular}{|c|c|c|c|c|}
\hline \multirow{3}{*}{$\begin{array}{l}\text { Panel A } \\
\text { Benchmarks }\end{array}$} & \multicolumn{4}{|c|}{ Buy-and-Hold Abnormal Return $(\mathrm{N}=3,661)$} \\
\hline & \multicolumn{2}{|c|}{ Three-Year Equal-Weighted } & \multicolumn{2}{|c|}{ Three-Year Value-Weighted } \\
\hline & $\begin{array}{c}\text { IPO } \\
\text { Return }\end{array}$ & BHAR & $\begin{array}{c}\text { IPO } \\
\text { Return }\end{array}$ & BHAR \\
\hline $\begin{array}{l}\text { CRSP VW index } \\
\text { (Skewness-adjusted t-statistic) }\end{array}$ & $8.5 \%$ & $\begin{array}{l}-16.7 \% \\
(-0.73)\end{array}$ & $6.3 \%$ & $\begin{array}{l}-19.9 \% \\
(-3.63)\end{array}$ \\
\hline $\begin{array}{l}\text { Size and Book-to-Market }(5 \times 5) \\
\text { (Skewness-adjusted t-statistic) }\end{array}$ & $8.5 \%$ & $\begin{array}{l}-8.4 \% \\
(-0.52)\end{array}$ & $6.3 \%$ & $\begin{array}{l}-11.5 \% \\
(-2.09)\end{array}$ \\
\hline
\end{tabular}

Panel B

Buy-and-Hold Abnormal Return $(\mathrm{N}=3,661)$

Five-Year Equal-Weighted Five-Year Value-Weighted

\begin{tabular}{|c|c|c|c|c|}
\hline Benchmarks & $\begin{array}{c}\text { IPO } \\
\text { Return }\end{array}$ & BHAR & $\begin{array}{c}\text { IPO } \\
\text { Return }\end{array}$ & BHAR \\
\hline $\begin{array}{l}\text { CRSP VW index } \\
\text { (Skewness-adjusted t-statistic) }\end{array}$ & $11.4 \%$ & $\begin{array}{l}-21.0 \% \\
(-0.81)\end{array}$ & $11.0 \%$ & $\begin{array}{l}-34.8 \% \\
(-3.87)\end{array}$ \\
\hline $\begin{array}{l}\text { Size and Book-to-Market }(5 \times 5) \\
\text { (Skewness-adjusted t-statistic) }\end{array}$ & $11.4 \%$ & $\begin{array}{l}-33.4 \% \\
(-0.31)\end{array}$ & $11.0 \%$ & $\begin{array}{l}-31.7 \% \\
(-3.64)\end{array}$ \\
\hline
\end{tabular}




\section{Table III (continued)}

\begin{tabular}{|c|c|c|c|c|}
\hline \multirow{3}{*}{$\begin{array}{l}\text { Panel C } \\
\text { Benchmarks }\end{array}$} & \multicolumn{4}{|c|}{ Buy-and-Hold Abnormal Return (with Spliced Data, N=3,661) } \\
\hline & \multicolumn{2}{|c|}{ Three-Year Equal-Weighted } & \multicolumn{2}{|c|}{ Three-Year Value-Weighted } \\
\hline & $\begin{array}{l}\text { IPO } \\
\text { Return }\end{array}$ & BHAR & $\begin{array}{l}\text { IPO } \\
\text { Return }\end{array}$ & BHAR \\
\hline $\begin{array}{l}\text { CRSP VW index } \\
\text { (Skewness-adjusted t-statistic) }\end{array}$ & $11.2 \%$ & $\begin{array}{l}-16.1 \% \\
(-0.75)\end{array}$ & $8.2 \%$ & $\begin{array}{l}-18.6 \% \\
(-3.05)\end{array}$ \\
\hline $\begin{array}{l}\text { Size and Book-to-Market }(5 \times 5) \\
\text { (Skewness-adjusted t-statistic) }\end{array}$ & $11.2 \%$ & $\begin{array}{l}-6.3 \% \\
(-0.40)\end{array}$ & $8.2 \%$ & $\begin{array}{l}-8.4 \% \\
(-1.40)\end{array}$ \\
\hline Panel D & \multicolumn{4}{|c|}{ Buy-and-Hold Abnormal Return (with Spliced Data, N=3,661) } \\
\hline & \multicolumn{2}{|c|}{ Five-Year Equal-Weighted } & \multicolumn{2}{|c|}{ Five-Year Value-Weighted } \\
\hline Benchmarks & $\begin{array}{l}\text { IPO } \\
\text { Return }\end{array}$ & BHAR & $\begin{array}{l}\text { IPO } \\
\text { Return }\end{array}$ & BHAR \\
\hline $\begin{array}{l}\text { CRSP VW index } \\
\text { (Skewness-adjusted t-statistic) }\end{array}$ & $25.8 \%$ & $\begin{array}{l}-11.5 \% \\
(-0.62)\end{array}$ & $17.2 \%$ & $\begin{array}{l}-32.0 \% \\
(-3.31)\end{array}$ \\
\hline $\begin{array}{l}\text { Size and Book-to-Market }(5 \times 5) \\
\text { (Skewness-adjusted t-statistic) }\end{array}$ & $25.8 \%$ & $\begin{array}{l}-34.8 \% \\
(-0.44)\end{array}$ & $17.2 \%$ & $\begin{array}{l}-28.9 \% \\
(-3.05)\end{array}$ \\
\hline
\end{tabular}




\section{Table IV}

\section{Three- and five-year post-initial public offering (IPO) cumulative abnormal returns versus various}

benchmarks.

The sample is 3,661 identified IPOs from 1935 through 1972. Three- and five-year cumulative abnormal returns (both equal-weighted and value-weighted) are compared with alternative benchmarks. In the first row of each panel, we employ the CRSP value-weighted index as the benchmark. Value-weighted results are adjusted for inflation. Row two of each panel presents abnormal performance measured relative to attributebased portfolios. Size and book-to-market portfolios are generated by first forming size quintile breakpoints using NYSE firms only. These quintiles are split further into book-to-market quintiles using NYSE breakpoints only. The universe of NYSE stocks is allocated into the resulting 25 portfolios and equalweighted monthly returns are calculated. The breakpoints for these portfolios are recalculated annually. Annual returns for the IPO firms are generated by calculating annual returns starting in the first month that a stock price in found in the Bank and Quotation Record following the equity issue. Abnormal return is the simple difference between IPO return in a given year and the designated benchmark. Cumulative abnormal returns are the simple three- or five-year sum of the annual abnormal returns. In Panels A and B, if the IPO delists before the fifth anniversary we compound the return up until the delisting year. In Panels $\mathrm{C}$ and $\mathrm{D}$, if the IPO delists before the fifth anniversary we splice in the return of the matched size and book-to-market benchmark.

Panel A Cumulative Abnormal Return (N=3,661)

Three-Year Equal-Weighted

Three-Year Value-Weighted

\begin{tabular}{lc|c}
\hline Benchmarks & CAR & CAR \\
\hline CRSP VW index & $-4.5 \%$ & $2.0 \%$ \\
(t-statistic) & $(-0.54)$ & $(0.41)$ \\
& & \\
Size and Book-to-Market $(5 \times 5)$ & $2.7 \%$ & $8.0 \%$ \\
(t-statistic) & $(0.32)$ & $(1.66)$ \\
\hline
\end{tabular}

Panel B

Cumulative Abnormal Return $(n=3,661)$

Five-Year Equal-Weighted

Five-Year Value-Weighted

\begin{tabular}{ll|c}
\hline Benchmarks & CAR & CAR \\
\hline CRSP VW index & $2.1 \%$ & $-0.5 \%$ \\
(t-statistic) & $(0.25)$ & $(-0.10)$ \\
& & \\
Size and Book-to-Market $(5 \times 5)$ & $-0.1 \%$ & $4.0 \%$ \\
(t-statistic) & $(-0.01)$ & $(0.79)$ \\
\hline
\end{tabular}


Table IV (continued)

Panel C

Cumulative Abnormal Return (with Spliced Data, N=3,661)

Three-Year Equal-Weighted

Three-Year Value-Weighted

\begin{tabular}{lc|c}
\hline Benchmarks & CAR & CAR \\
\hline CRSP VW index & $-5.0 \%$ & $1.3 \%$ \\
(t-statistic) & $(-0.60)$ & $(0.26)$ \\
& & \\
Size and Book-to-Market (5x5) & $2.7 \%$ & $8.0 \%$ \\
(t-statistic) & $(0.32)$ & $(1.66)$ \\
\hline
\end{tabular}

Panel D

Cumulative Abnormal Return (with Spliced Data, N=3,661)

Five-Year Equal-Weighted Five-Year Value-Weighted

\begin{tabular}{lc|c}
\hline Benchmarks & CAR & CAR \\
\hline CRSP VW index & $8.7 \%$ & $0.3 \%$ \\
(t-statistic) & $(1.02)$ & $(0.06)$ \\
& & \\
Size and Book-to-Market (5x5) & $-0.1 \%$ & $4.0 \%$ \\
(t-statistic) & $(-0.01)$ & $(0.79)$ \\
\hline \hline
\end{tabular}


Table V

Event-Time Returns on IPOs by Cohort Year

The sample is 3,661 identified IPOs from 1935 through 1972. Five-year equal-weighted buy-and-hold and cumulative abnormal returns are compared with alternative benchmarks in each cohort year. We employ both the CRSP value-weighted index and an attribute-based portfolio as the benchmark. Value-weighted results are adjusted for inflation. Size and book-to-market portfolios are generated by first forming size quintile breakpoints using NYSE firms only. These quintiles are split further into book-to-market quintiles using NYSE breakpoints only. The universe of NYSE stocks is allocated into the resulting 25 portfolios and equal-weighted monthly returns are calculated. The breakpoints for these portfolios are recalculated annually. Annual returns for the IPO firms are generated by calculating annual returns starting in the first month that a stock price is found in the Bank and Quotation Record following the equity issue. Abnormal return is the simple difference between IPO return in a given year and the designated benchmark. Cumulative abnormal returns are the simple five-year sum of the annual abnormal returns. Buy-and-hold returns are generated by compounding annual returns. If the IPO delists before the fifth anniversary we splice in the return of the matched size and book-to-market benchmark.

\begin{tabular}{|c|c|c|c|c|}
\hline \multirow[b]{2}{*}{ Year } & \multicolumn{2}{|c|}{ Five-Year Buy-and-Hold Returns } & \multicolumn{2}{|c|}{ Five-Year Cumulative Abnormal Returns } \\
\hline & $\begin{array}{l}\text { EW IPOs-EW Size and } \\
\text { Book-to-Market Benchmarks }\end{array}$ & $\begin{array}{l}\text { EW IPOs- CRSP VW } \\
\text { Index }\end{array}$ & $\begin{array}{l}\text { EW IPOs-EW Size and Book-to- } \\
\text { Market Benchmarks }\end{array}$ & $\begin{array}{l}\text { EW IPOs- CRSP VW } \\
\text { Index }\end{array}$ \\
\hline 1935 & $67.0 \%$ & $14.0 \%$ & $109.1 \%$ & $16.6 \%$ \\
\hline 1936 & $157.4 \%$ & $129.2 \%$ & $96.0 \%$ & $54.7 \%$ \\
\hline 1937 & $-67.1 \%$ & $-54.7 \%$ & $-46.6 \%$ & $-26.7 \%$ \\
\hline 1938 & $58.0 \%$ & $73.7 \%$ & $44.0 \%$ & $62.0 \%$ \\
\hline 1939 & $-219.3 \%$ & $-65.8 \%$ & $-55.6 \%$ & $41.2 \%$ \\
\hline 1940 & $-212.2 \%$ & $-65.1 \%$ & $-105.0 \%$ & $-27.6 \%$ \\
\hline 1941 & $-59.3 \%$ & $124.8 \%$ & $-34.1 \%$ & $64.0 \%$ \\
\hline 1942 & $116.9 \%$ & $168.6 \%$ & $41.0 \%$ & $105.1 \%$ \\
\hline 1943 & $-41.3 \%$ & $-45.7 \%$ & $0.4 \%$ & $12.9 \%$ \\
\hline 1944 & $1.1 \%$ & $-12.0 \%$ & $-19.9 \%$ & $-11.0 \%$ \\
\hline 1945 & $22.0 \%$ & $-32.2 \%$ & $53.4 \%$ & $17.8 \%$ \\
\hline 1946 & $-44.5 \%$ & $-93.5 \%$ & $-6.9 \%$ & $-32.4 \%$ \\
\hline 1947 & $18.3 \%$ & $-46.5 \%$ & $7.7 \%$ & $-30.1 \%$ \\
\hline 1948 & $0.6 \%$ & $-76.0 \%$ & $4.4 \%$ & $-38.8 \%$ \\
\hline 1949 & $-19.9 \%$ & $-150.3 \%$ & $-13.6 \%$ & $-87.1 \%$ \\
\hline 1950 & $-24.9 \%$ & $-124.6 \%$ & $-18.8 \%$ & $-79.4 \%$ \\
\hline 1951 & $-45.6 \%$ & $-87.9 \%$ & $-29.1 \%$ & $-55.7 \%$ \\
\hline 1952 & $-28.7 \%$ & $-74.1 \%$ & $31.2 \%$ & $4.3 \%$ \\
\hline 1953 & $-31.8 \%$ & $-4.0 \%$ & $16.1 \%$ & $37.1 \%$ \\
\hline 1954 & $-43.9 \%$ & $-48.9 \%$ & $-47.3 \%$ & $-36.1 \%$ \\
\hline 1955 & $-54.0 \%$ & $-34.9 \%$ & $-35.9 \%$ & $-13.5 \%$ \\
\hline 1956 & $-36.3 \%$ & $-22.9 \%$ & $-30.5 \%$ & $-8.3 \%$ \\
\hline 1957 & $-36.8 \%$ & $-40.7 \%$ & $-13.1 \%$ & $-6.1 \%$ \\
\hline 1958 & $55.3 \%$ & $21.7 \%$ & $78.5 \%$ & $61.4 \%$ \\
\hline 1959 & $-33.8 \%$ & $-38.9 \%$ & $-0.1 \%$ & $0.6 \%$ \\
\hline 1960 & $-25.4 \%$ & $13.6 \%$ & $29.6 \%$ & $60.2 \%$ \\
\hline 1961 & $-222.4 \%$ & $-53.4 \%$ & $-63.8 \%$ & $21.1 \%$ \\
\hline 1962 & $-209.7 \%$ & $31.1 \%$ & $-78.3 \%$ & $37.9 \%$ \\
\hline 1963 & $245.2 \%$ & $467.0 \%$ & $41.1 \%$ & $158.9 \%$ \\
\hline 1964 & $104.1 \%$ & $181.6 \%$ & $39.9 \%$ & $134.3 \%$ \\
\hline 1965 & $53.4 \%$ & $92.6 \%$ & $32.8 \%$ & $93.0 \%$ \\
\hline 1966 & $612.0 \%$ & $622.6 \%$ & $473.2 \%$ & $503.3 \%$ \\
\hline 1967 & $41.3 \%$ & $-23.8 \%$ & $134.8 \%$ & $67.5 \%$ \\
\hline 1968 & $32.3 \%$ & $-22.7 \%$ & $76.3 \%$ & $-1.1 \%$ \\
\hline 1969 & $-24.0 \%$ & $-71.6 \%$ & $-19.9 \%$ & $-62.4 \%$ \\
\hline 1970 & $-11.0 \%$ & $-48.9 \%$ & $-7.2 \%$ & $-29.5 \%$ \\
\hline 1971 & $-17.1 \%$ & $-39.2 \%$ & $-2.8 \%$ & $-7.3 \%$ \\
\hline 1972 & $-77.5 \%$ & $-3.9 \%$ & $-60.4 \%$ & $3.8 \%$ \\
\hline Average & $0.0 \%$ & $14.7 \%$ & $16.3 \%$ & $26.4 \%$ \\
\hline t-statistic & $(0.00)$ & $(0.61)$ & (1.09) & (1.68) \\
\hline
\end{tabular}


Table VI

Calendar-time Returns on IPOs

The sample is 3,661 identified IPOs from 1935 through 1972. The annual abnormal returns (both equal-weighted and value-weighted) are compared with alternative benchmarks in each year. Each year, the return on all IPOs in the sample that went public within the past five years is calculated. The returns are either equally weighted or weighted by market capitalization at IPO (in constant 1999 dollars). The annual benchmark returns are the annual returns on either the CRSP value-weighted index or the matched size and book-to-market index. The final column presents the annual excess return on small, low book-to-market non-issuing firms relative to the CRSP valueweighted index.

\begin{tabular}{|c|c|c|c|c|c|}
\hline Year & $\begin{array}{l}\text { EW IPOs- CRSP } \\
\text { VW Index }\end{array}$ & $\begin{array}{l}\text { VW IPOs - CRSP } \\
\text { VW Index }\end{array}$ & $\begin{array}{l}\text { EW IPOs-EW Size and Book- } \\
\text { to-Market Benchmarks }\end{array}$ & $\begin{array}{l}\text { VW IPOs- VW Size and } \\
\text { Book-to-Market Benchmarks }\end{array}$ & $\begin{array}{l}\text { Excess Return on } \\
(1,1) \text { Portfolio }\end{array}$ \\
\hline 1936 & $-46.4 \%$ & $-46.4 \%$ & $-37.5 \%$ & $-37.5 \%$ & $-6.8 \%$ \\
\hline 1937 & $10.7 \%$ & $1.5 \%$ & $35.8 \%$ & $19.0 \%$ & $-32.2 \%$ \\
\hline 1938 & $-1.3 \%$ & $-6.1 \%$ & $-12.1 \%$ & $-20.1 \%$ & $4.9 \%$ \\
\hline 1939 & $28.8 \%$ & $48.3 \%$ & $34.2 \%$ & $45.4 \%$ & $-17.8 \%$ \\
\hline 1940 & $17.2 \%$ & $14.3 \%$ & $19.2 \%$ & $9.4 \%$ & $-7.1 \%$ \\
\hline 1941 & $1.1 \%$ & $2.7 \%$ & $18.4 \%$ & $7.2 \%$ & $-45.3 \%$ \\
\hline 1942 & $-6.7 \%$ & $3.5 \%$ & $-15.1 \%$ & $1.2 \%$ & $7.8 \%$ \\
\hline 1943 & $25.9 \%$ & $14.8 \%$ & $-0.8 \%$ & $9.4 \%$ & $9.3 \%$ \\
\hline 1944 & $8.6 \%$ & $19.1 \%$ & $-22.9 \%$ & $15.5 \%$ & $50.8 \%$ \\
\hline 1945 & $50.8 \%$ & $30.8 \%$ & $8.4 \%$ & $22.1 \%$ & $50.3 \%$ \\
\hline 1946 & $-4.4 \%$ & $-11.2 \%$ & $-1.1 \%$ & $-6.2 \%$ & $2.5 \%$ \\
\hline 1947 & $-8.8 \%$ & $-9.3 \%$ & $-0.5 \%$ & $-5.3 \%$ & $-8.9 \%$ \\
\hline 1948 & $-6.0 \%$ & $-8.6 \%$ & $3.7 \%$ & $-2.4 \%$ & $-8.1 \%$ \\
\hline 1949 & $8.0 \%$ & $7.0 \%$ & $12.0 \%$ & $6.2 \%$ & $-12.8 \%$ \\
\hline 1950 & $-3.2 \%$ & $-3.1 \%$ & $-8.2 \%$ & $-15.0 \%$ & $-0.6 \%$ \\
\hline 1951 & $-4.2 \%$ & $-5.5 \%$ & $1.2 \%$ & $-1.6 \%$ & $-2.5 \%$ \\
\hline 1952 & $-7.8 \%$ & $-25.2 \%$ & $6.0 \%$ & $-20.8 \%$ & $-27.3 \%$ \\
\hline 1953 & $-6.8 \%$ & $-10.2 \%$ & $1.3 \%$ & $-10.4 \%$ & $-16.7 \%$ \\
\hline 1954 & $-21.7 \%$ & $-22.1 \%$ & $-20.6 \%$ & $-23.2 \%$ & $-14.5 \%$ \\
\hline 1955 & $-2.1 \%$ & $-6.2 \%$ & $5.6 \%$ & $-6.1 \%$ & $-13.8 \%$ \\
\hline 1956 & $-11.6 \%$ & $-14.1 \%$ & $-3.7 \%$ & $-11.6 \%$ & $-13.6 \%$ \\
\hline 1957 & $0.2 \%$ & $-2.5 \%$ & $0.8 \%$ & $-3.8 \%$ & $-2.1 \%$ \\
\hline 1958 & $-2.3 \%$ & $-8.5 \%$ & $-50.4 \%$ & $-27.4 \%$ & $70.8 \%$ \\
\hline 1959 & $8.3 \%$ & $-9.6 \%$ & $2.3 \%$ & $-17.3 \%$ & $-1.0 \%$ \\
\hline 1960 & $4.1 \%$ & $28.6 \%$ & $16.8 \%$ & $29.8 \%$ & $-20.0 \%$ \\
\hline 1961 & $5.3 \%$ & $15.1 \%$ & $1.7 \%$ & $14.0 \%$ & $3.4 \%$ \\
\hline 1962 & $-29.3 \%$ & $-15.6 \%$ & $-22.3 \%$ & $-9.4 \%$ & $-7.6 \%$ \\
\hline 1963 & $-8.4 \%$ & $12.7 \%$ & $-23.5 \%$ & $7.5 \%$ & $23.5 \%$ \\
\hline 1964 & $7.1 \%$ & $-7.7 \%$ & $3.7 \%$ & $-12.0 \%$ & $2.9 \%$ \\
\hline 1965 & $52.5 \%$ & $21.3 \%$ & $24.1 \%$ & $12.1 \%$ & $27.2 \%$ \\
\hline 1966 & $9.7 \%$ & $11.0 \%$ & $0.3 \%$ & $8.9 \%$ & $10.8 \%$ \\
\hline 1967 & $109.7 \%$ & $-12.3 \%$ & $15.8 \%$ & $-34.0 \%$ & $115.3 \%$ \\
\hline 1968 & $47.9 \%$ & $38.4 \%$ & $13.2 \%$ & $12.7 \%$ & $31.1 \%$ \\
\hline 1969 & $-1.8 \%$ & $-6.8 \%$ & $12.8 \%$ & $2.8 \%$ & $-15.1 \%$ \\
\hline 1970 & $-29.4 \%$ & $-26.8 \%$ & $-6.2 \%$ & $-7.9 \%$ & $-28.2 \%$ \\
\hline 1971 & $19.6 \%$ & $11.9 \%$ & $8.5 \%$ & $-0.9 \%$ & $12.7 \%$ \\
\hline 1972 & $-9.8 \%$ & $-6.8 \%$ & $6.4 \%$ & $6.1 \%$ & $-17.3 \%$ \\
\hline 1973 & $-20.3 \%$ & $-22.9 \%$ & $1.2 \%$ & $-3.2 \%$ & $-24.7 \%$ \\
\hline 1974 & $-1.9 \%$ & $-5.6 \%$ & $-4.3 \%$ & $-6.5 \%$ & $0.9 \%$ \\
\hline 1975 & $30.9 \%$ & $44.7 \%$ & $-4.3 \%$ & $13.1 \%$ & $31.5 \%$ \\
\hline 1976 & $13.1 \%$ & $13.3 \%$ & $-9.2 \%$ & -6.1 & $21.8 \%$ \\
\hline $\begin{array}{l}\text { Average Annual } \\
\text { Abnormal Return } \\
\text { Median Annual }\end{array}$ & $5.5 \%$ & $1.1 \%$ & $0.3 \%$ & $-1.1 \%$ & $3.3 \%$ \\
\hline $\begin{array}{l}\text { Abnormal Return } \\
\text { t-statistic }\end{array}$ & $-1.3 \%$ & $-5.5 \%$ & $1.2 \%$ & $-2.4 \%$ & $-2.1 \%$ \\
\hline t-statıstic & $(1.34)$ & $(0.10)$ & $(0.10)$ & $(0.43)$ & \\
\hline
\end{tabular}


Table VII

\section{Correlation between Calendar-time IPO Returns and Number of IPOs in Calendar-time Portfolio}

The sample is 3,661 identified IPOs from 1935 through 1972. The correlation coefficient between the annual abnormal return of the IPOs (both equal-weighted and value-weighted) relative to the matched size and book-to-market benchmarks and the CRSP value-weighted index in each year and the number of IPOs in the annual portfolio is calculated. Each year, the return on all IPOs in the sample that went public within the past five years is calculated. The returns are either equally weighted or weighted by market capitalization at IPO (in constant 1999 dollars). The annual benchmark returns are the annual returns on either the CRSP value-weighted index or the matched size and book-to-market index.

\begin{tabular}{|c|c|c|c|c|c|}
\hline & $\begin{array}{l}\text { EW IPOs-EW Size } \\
\text { and Book-to-Market } \\
\text { Benchmarks }\end{array}$ & $\begin{array}{l}\text { VW IPOs -VW Size } \\
\text { and Book-to-Market } \\
\text { Benchmarks }\end{array}$ & $\begin{array}{l}\text { EW IPOs- CRSP VW } \\
\text { index }\end{array}$ & $\begin{array}{l}\text { VW IPOs- CRSP VW } \\
\text { index }\end{array}$ & $\begin{array}{l}\text { Number of IPOs in } \\
\text { Portfolio }\end{array}$ \\
\hline $\begin{array}{l}\text { EW IPOs-EW Size } \\
\text { and Book-to-Market } \\
\text { Benchmarks }\end{array}$ & 1.000 & & & & \\
\hline $\begin{array}{l}\text { VW IPOs -VW Size } \\
\text { and Book-to-Market } \\
\text { Benchmarks }\end{array}$ & $\begin{array}{r}0.571 \\
(0.000)\end{array}$ & 1.000 & & & \\
\hline $\begin{array}{l}\text { EW IPOs- CRSP } \\
\text { VW index }\end{array}$ & $\begin{array}{r}0.501 \\
(0.001)\end{array}$ & $\begin{array}{r}0.294 \\
(0.089)\end{array}$ & 1.000 & & \\
\hline $\begin{array}{l}\text { VW IPOs- CRSP } \\
\text { VW index }\end{array}$ & $\begin{array}{r}0.416 \\
(0.007)\end{array}$ & $\begin{array}{r}0.820 \\
(0.000)\end{array}$ & $\begin{array}{r}0.590 \\
(0.000)\end{array}$ & 1.000 & \\
\hline $\begin{array}{l}\text { Number of IPOs in } \\
\text { Portfolio }\end{array}$ & $\begin{array}{r}-0.015 \\
(0.928)\end{array}$ & $\begin{array}{r}0.030 \\
(0.852)\end{array}$ & $\begin{array}{r}-0.143 \\
(0.171)\end{array}$ & $\begin{array}{r}-0.098 \\
(0.340)\end{array}$ & 1.000 \\
\hline
\end{tabular}




\section{Table VIII}

\section{CAPM and Fama-French (1993) three factor regression on initial public offering (IPO) portfolios}

The sample is 3,661 identified IPOs from 1935 through 1972. Portfolios of IPOs include all issues that were completed within the previous five years. RMRF is the value-weighted market return on all NYSE stocks (RM) minus the risk free rate $(\mathrm{RF})$, which is the one-month Treasury bill rate. SMB (small minus big) is the difference each month between the return on small firms and big firms. HML (high minus low) is the difference each month between the return on a portfolio of high book-to-market stocks and the return on a portfolio of low book-to-market stocks. The first two columns present results for the CAPM regressions. The next two columns present FamaFrench three factor regressions (t-statistics are in parentheses). Panel A estimates ordinary least squares regressions while Panel B uses weighted least squares where observations are weighted by the square root of the number of IPO firms in the portfolio in a given year.

Panel A: Ordinary Least Squares

\begin{tabular}{|c|c|c|c|c|}
\hline & Equal-Weighted & Value-Weighted & Equal-Weighted & Value-Weighted \\
\hline Intercepts & $\begin{array}{c}0.044 \\
(1.01)\end{array}$ & $\begin{array}{l}0.008 \\
(0.25)\end{array}$ & $\begin{array}{l}0.082 \\
(2.90)\end{array}$ & $\begin{array}{c}0.038 \\
(1.18)\end{array}$ \\
\hline RMRF & $\begin{array}{c}1.180 \\
(5.80)\end{array}$ & $\begin{array}{l}1.068 \\
(6.94)\end{array}$ & $\begin{array}{c}0.689 \\
(5.07)\end{array}$ & $\begin{array}{c}0.858 \\
(5.56)\end{array}$ \\
\hline SMB & & & $\begin{array}{l}1.831 \\
(8.43)\end{array}$ & $\begin{array}{l}0.855 \\
(3.47)\end{array}$ \\
\hline HML & & & $\begin{array}{l}-0.551 \\
(-2.42)\end{array}$ & $\begin{array}{c}-0.444 \\
(-1.71)\end{array}$ \\
\hline Adjusted $\mathrm{R}^{2}$ & 0.449 & 0.541 & 0.824 & 0.669 \\
\hline
\end{tabular}

Panel B: Weighted Least Squares (Weights Equal to Number of IPOs in Portfolio)

\begin{tabular}{l|c|c|c|c}
\hline & Equal-Weighted & Value-Weighted & Equal-Weighted & Value-Weighted \\
\hline \multirow{2}{*}{ Intercepts } & 0.034 & 0.001 & 0.077 & 0.0299 \\
& $(0.86)$ & $(0.05)$ & $(3.25)$ & $(1.01)$ \\
& 1.396 & 1.282 & 0.798 & 1.021 \\
RMRF & $(7.03)$ & $(8.99)$ & $(7.11)$ & $(7.31)$ \\
& & & 1.542 & 0.801 \\
SMB & & & $(10.42)$ & $(3.57)$ \\
& & & -0.350 & -0.297 \\
HML & & & $(-1.75)$ & $(-1.19)$ \\
& & & 0.891 & 0.757 \\
\hline \multirow{2}{*}{ Adjusted $\mathrm{R}^{2}$} & & & & \\
\hline \hline
\end{tabular}

